\title{
Potato Maximum Yield as Affected by Crop Parameters and Climatic Factors in Brazil
}

\author{
André Pereira ${ }^{1,3}$ and Nilson Villa Nova ${ }^{2}$ \\ Department of Soil Science and Agricultural Engineering, State University of \\ Ponta Grossa-UEPG, 4748 Carlos Cavalcanti Avenue, Agronomy Building, \\ Ponta Grossa, Parana 84030-900, Brazil
}

Additional index words. modeling, Solanum tuberosum L., meteorological data, harvest index, potential yield

\begin{abstract}
There is currently a great deal of interest in estimating crop productivity as a function of climatic factors by means of different crop weather models. In this article, an agrometeorological model based on maximum carbon dioxide assimilation rates for $\mathrm{C}_{3}$ plants, fraction of photosynthetically active radiation, air temperature, photoperiod duration, and crop parameters is assessed as to its performance under tropical conditions. Crop parameters include leaf area, harvest index, dry matter content of potato tubers, and crop cycles to estimate potential potato yields. Productivity obtained with the cultivar Itararé, grown with adequate soil water supply conditions at four different sites in the state of São Paulo (Itararé, Piracicaba, Tatuí, and São Manuel), Brazil, was used to test the model. The results revealed excellent performance of the agrometeorological model proposed here with an underestimation of irrigated potato productivity of less than $10 \%$.
\end{abstract}

We considered potential yield to be the maximum possible yield of a given species or cultivar achievable under the existing conditions of solar radiation flux density with all the other environmental factors considered to be optimal. Therefore, the potential yield is determined by the biological properties of the cultivar and radiation resources available. Potential yield expresses the solar radiation resources for cultivating a given genotype in yield units, whereas the commercial yield is the yield attainable under existing farm conditions that takes into account all the factors limiting the production process and the crop yield.

Meteorological factors directly influence potential crop productivity, regulating its transpiration, photosynthesis, and respiration processes in such a way as to control the growth and development of the plants throughout their physiological mechanisms at a given site. The interaction of the meteorological factors with the crop responses is complex. However, by assessing physiolog-

\footnotetext{
Received for publication 27 Nov. 2007. Accepted for publication 18 Mar. 2008.

The access to the meteorological data provided by the Agrometeorology Division of the Instituto Agronômico de Campinas (IAC) by means of Dr. Orivaldo Brunini and Dr. Mario J. Pedro Junior is greatly appreciated. Many thanks are owed to the Conselho Nacional de Desenvolvimento Científico e Tecnológico ( $\mathrm{CNPq}$ ) for the provision of the productivity scholarship as well as to Sandy Shelton, MSc, from San Francisco, CA, for the thorough revision on the English of this manuscript.

${ }^{1}$ Associate Professor.

${ }^{2}$ Associate Professor and Brazilian Federal Funding Agency Researcher.

${ }^{3}$ To whom reprint requests should be addressed; e-mail andre.pereira@pq.cnpq.br
}

similation could not explain the yield reduction observed; the temperature effect on assimilation was not as dramatic as it was on growth or yield. Other workers have reported a severe reduction in the rate of assimilation at air temperatures above $30^{\circ} \mathrm{C}$ under controlled experimental conditions. In such cases, reductions in $\mathrm{CO}_{2}$ assimilation rate were shown to correlate well with reductions in growth and yield (Ku et al., 1977; Midmore and Prange, 1992). These results reveal the complexity of plant responses to the combined effects of water and temperature stress, which inevitably occur in association under field conditions (Pereira and Shock, 2006).

Knowledge of climatic requirements of potato and its physiological responses to the environment is extremely important to help growers produce high yields with good tuber quality under site-specific atmospheric conditions. The potato growth models included in DSSAT (Decision Support System for Agrotechnology Transfer) are SUBSTORPOTATO and LINTUL-POTATO (University of Hawaii, Honolulu, Hawaii). The SUBSTOR-Potato crop soil weather model takes into consideration daily air temperature, photoperiod, intercepted solar radiation, soil water, and nitrogen supply. The model simulated fresh tuber yields ranging from $4 \mathrm{t} \cdot \mathrm{ha}^{-1}$ to $56 \mathrm{t} \cdot \mathrm{ha}^{-1}$ resulting from differences in weather patterns, soils, cultivars, and management practices (Bowen, 2003).

Kadaja and Tooming (2004) proposed a relatively simple model, POMOD, to calculate potato yield, which permits integration of the knowledge in different disciplines on the potato crop yield levels using the measured physiological, ecological, agrometeorological, and agronomical parameters of the plant. The input variables of the model can be divided into four groups: daily meteorological information, annual information, location, and cultivar. The first group includes global radiation, air temperature, and precipitation. The location is characterized by geographical latitude and hydrological parameters. As to cultivar, the parameters of gross and net photosynthesis, the coefficients of growth and maintenance respiration, and albedo of the crop are also needed.

The LINTUL-POTATO simulation model (Kooman and Haverkort, 1995) establishes potential yield of a certain cultivar for a determined growing period and plant density and is based on incident $P A R$, the fraction of $P A R$ intercepted by the crop, and radiation use efficiency to produce dry matter. Phenological crop development is driven by accumulated degree-days, whereas development stage determines dry matter partitioning and the pattern of intercepted $P A R$ is defined through growth. The potential yield established with this simulation model was used by Caldiz and Struit (1999) to perform a preliminary yield gap analysis regarding actual and attainable potato yield in different areas of Argentina.

We tested the performance of a model based on studies of maximum rates of carbon 
dioxide assimilation for a $\mathrm{C}_{3}$ crop as a function of air temperature, a fraction of global solar radiation flux density $(P A R)$, photoperiod duration, and leaf area index to estimate the potential productivity of potato. To assess the performance of the proposed mathematical model, the estimated values of tuber yield were compared with observed productivity data under irrigation conditions for the studied sites. The present study was similar to the potential productivity estimation model described by Villa Nova et al. (2001) and used by Villa Nova et al. (2005) for sugar cane in Piracicaba, São Paulo, Brazil.

\section{Materials and Methods}

The proposed model for the estimation of potato potential yield (EPY, $t \cdot h a^{-1}$ ), expressed by Eq. [1], is based on the concept that the maximum rate of dioxide carbon assimilation by the plants for production of carbohydrate $\left(\mathrm{CH}_{2} \mathrm{O}\right)$ is related to the active photosynthetically fraction of the solar spectrum $(P A R)$ and air temperature:

$$
\begin{aligned}
\mathrm{EPY}= & 1.27 * 10^{-6} * \mathrm{CDA} * \mathrm{LAI} * \mathrm{GS} * \\
& \mathrm{~N} * \mathrm{C}(\mathrm{LAI}) * \mathrm{C}(\mathrm{T}) * \mathrm{HI} * \frac{100}{\mathrm{DM}}
\end{aligned}
$$

where CDA is the carbon dioxide assimilation rate $\left(\mu \mathrm{L} \cdot \mathrm{cm}^{-2} \cdot \mathrm{h}^{-1}\right), \mathrm{LAI}$ is the maximum leaf area index, GS is the number of days of the crop growing season, $\mathrm{N}$ is the mean photoperiod or daylength duration throughout of the crop growing season (hours), $\mathrm{C}(\mathrm{LAI})$ is the correction factor for leaf area index variation over time, $\mathrm{C}(\mathrm{T})$ is the correction factor for maintenance respiration, $\mathrm{HI}$ is the harvest index, and DM is the dry matter content of the potato tubers (\%).

Making use of the Clausius-Clapeyron's equation with the masses of $\mathrm{CO}_{2}$ equal to $44 \mathrm{~g} \cdot \mathrm{mol}^{-1}$ and of $\mathrm{CH}_{2} \mathrm{O}$ corresponding to $30 \mathrm{~g} \cdot \mathrm{mol}^{-1}$, and considering $1 \mu \mathrm{L}$ of $\mathrm{CO}_{2}$ at $15{ }^{\circ} \mathrm{C}(288 \mathrm{~K})$ and 1 atmosphere equal to $1.863 * 10^{-6} \mathrm{~g} \mathrm{CO}_{2}$, one can infer that the $\mathrm{CH}_{2} \mathrm{O} / \mathrm{CO}_{2}$ ratio assumes a value of $1.27 *$ $10^{-6} \mathrm{~g} \mathrm{CH}_{2} \mathrm{O} / \mu \mathrm{L} \mathrm{CO} \mathrm{CO}_{2}$ (Villa Nova et al., 2001).

Applying the necessary corrections to the aforementioned equation to express the estimates of potato potential yield in tons per hectare per crop cycle, we have:

$$
\begin{aligned}
\mathrm{EPY}= & 1.27 * 10^{-4} * \mathrm{CDA} * \mathrm{LAI} * \mathrm{GS} * \\
& \mathrm{~N} * \mathrm{C}(\mathrm{LAI}) * \mathrm{C}(\mathrm{T}) * \mathrm{HI} * \frac{100}{\mathrm{DM}}
\end{aligned}
$$

Without considering $\mathrm{HI}$, the product of the other terms of the Eq. [2] depicts the estimation of the total dry matter produced by the potato plants, including roots, leaves, and shoots.

Plotted and interpolated values of CDA were obtained from a graph that shows the relation between air temperature and maximum rate of $\mathrm{CO}_{2}$ assimilation for a $\mathrm{C}_{3}$ crop species under controlled conditions (van Heemst, 1986) as a function of the ambient temperature $(\mathrm{T})$ and $P A R$. However, under field conditions where plants are subjected to fluctuating temperature conditions, there appears to be adaptation of the photosynthetic apparatus. Thus, such plotted and interpolated CDA data are described mathematically by the following equation (Penning de Vries et al., 1989):

$$
\mathrm{CDA}=\mathrm{CDA}_{\max }\left[1-e^{\frac{-0.5^{*} P A R}{C D A_{\max }}}\right]
$$

where $\mathrm{CDA}_{\max }$ is the maximum carbon dioxide assimilation rate of $48 \mu \mathrm{L} \cdot \mathrm{cm}^{-2} \cdot \mathrm{h}^{-1}$.

The $P A R$, expressed in $\mathrm{J} \cdot \mathrm{m}^{-2} \cdot \mathrm{s}^{-1}$, was calculated by the equation proposed by Assunção (1994) as a function of the global solar radiation flux density and insolation ratio:

$$
P A R=\frac{\mathrm{Qg}}{3600 * N} *\left[0.5-0.1 *\left(\frac{\mathrm{n}}{\mathrm{N}}\right)\right]
$$

where Qg is the mean global solar radiation flux density throughout the crop growing season $\left(\mathrm{J} \cdot \mathrm{m}^{-2} \cdot \mathrm{d}^{-1}\right), \mathrm{N}$ is the mean photoperiod during the crop cycle (hours), and $\mathrm{n} / \mathrm{N}$ is the actual mean insolation ratio of the period.

The global solar radiation flux density $(\mathrm{Qg})$ was estimated taking into account the mean values of $a$ and $b$ Angstrom's coefficients obtained by Cervellini et al. (1966) for the State of São Paulo, Brazil. The equation used for the sites where no radiometric measurements were available for the current study was the following:

$$
\mathrm{Qg}=\mathrm{Qo}\left[0.24+0.58 * \frac{\mathrm{n}}{\mathrm{N}}\right]
$$

where Qo is the extraterrestrial radiation, expressed in $\mathrm{J} \cdot \mathrm{m}^{-2} \cdot \mathrm{d}^{-1}$, having been determined by the subsequent expression:

$$
\begin{aligned}
Q o= & 38.32 * 10^{6}[h * \sin \delta * \sin \varphi+ \\
& \cos \delta * \cos \varphi * \sin H]
\end{aligned}
$$

where $38.32 * 10^{6}$ is the mean value of corrected solar constant converted into $\mathrm{J} \cdot \mathrm{m}^{-2} \cdot \mathrm{d}^{-1}$, given by Crommelynk and Fichot (1997), $\mathrm{H}$ is the semiarc from the meridian crossing of the sun to sunset in degrees, $\mathrm{h}$ is the diurnal semiarc in radians, $\delta$ is the solar declination in degrees, and $\varphi$ is the local latitude in degrees.

The equations that defined $\delta, \mathrm{H}$, and $\mathrm{N}$ (Pereira et al., 2003) were:

$$
\delta=23.45 * \sin \left[\frac{360}{365} *(D J-80)\right]
$$

where $D J$ is the number of days since the first day of January up to the considered date.

$$
\begin{gathered}
\mathrm{H}=\arccos [-\tan \delta * \tan \varphi] \\
\mathrm{N}=\frac{2 * \mathrm{H}}{15}
\end{gathered}
$$

The number of hours of insolation (n) was measured with a Campbell-Stockes sunshine recorder installed at the four weather stations where the studies were carried out.
All the meteorological data used as input variables of the potato potential yield model were obtained from conventional weather stations set up at research locations of the Agronomic Institute of Campinas, IAC, University of São Paulo, ESALQ/USP, and State University of São Paulo, FCA/UNESP. These governmental institutions of the state of São Paulo provided the necessary meteorological data for the municipalities of Itararé, Tatuí, Piracicaba, and São Manuel, São Paulo, Brazil.

The climate of Tatuí $\left(23^{\circ} 22^{\prime} \mathrm{S}, 47^{\circ} 52^{\prime} \mathrm{W}\right.$ Gr., and $600 \mathrm{~m})$, Piracicaba $\left(22^{\circ} 43^{\prime} \mathrm{S}\right.$, $47^{\circ} 25^{\prime} \mathrm{W}$ Gr., and $580 \mathrm{~m}$ ), and São Manuel $\left(22^{\circ} 44^{\prime} \mathrm{S}, 48^{\circ} 34^{\prime} \mathrm{W}\right.$ Gr., and $\left.700 \mathrm{~m}\right)$ is classified as Cwa or subtropical with rains in the summer and dry winter according to the Köppen System. The climate of Itararé city $\left(24^{\circ} 06^{\prime} \mathrm{S}, 49^{\circ} 20^{\prime} \mathrm{W}\right.$ Gr., and $\left.1150 \mathrm{~m}\right)$ in the state of São Paulo, Brazil, is classified as Cfb or rainy temperate of altitude, constantly wet throughout the year.

The values of $\mathrm{C}(\mathrm{T})$ equal to 0.6 and 0.5 were adopted whenever the mean air temperatures throughout the crop-growing season were below or above $20^{\circ} \mathrm{C}$, respectively, as recommended by Doorenbos and Kassam (1979). The value of C(LAI) was calculated by the equation described by Villa Nova et al. (2001) as follows:

$$
\mathrm{C}(\mathrm{LAI})=\frac{1-e^{-0.8^{*} \mathrm{LAI}}}{2}
$$

The ratio between harvested yield and net total dry matter is given by the HI for highproducing cultivars under irrigation. For potato, whose commercial product is the tuber, HI varies from 0.55 to 0.65 (Doorenbos and Kassam, 1979). For practical purposes, we adopted the mean value corresponding to 0.6 to calculate the final crop production.

The maximum LAI for the cultivar Itararé (IAC-5986) was determined experimentally in the field by Varillas (1991) and Robles (2003) under the climatic conditions of Itararé and Piracicaba.

The dry matter content of the tubers is intimately related to the tuber-specific gravity. To measure tuber-specific gravity, the weight-in-air/weight-in-water method was used. For that, a random sample of tubers was first weighed in air $\left(\mathrm{W}_{\text {air }}\right)$ and, after submerging the tubers in water, weighed again $\left(\mathrm{W}_{\text {water }}\right)$. Thus, specific gravity (SG) was calculated using the following formula (Stark and Love, 2003):

$$
\mathrm{SG}=\frac{\mathrm{W}_{\text {air }}}{\mathrm{W}_{\text {air }}-\mathrm{W}_{\text {water }}}
$$

Dry matter content of the tubers in percentage was determined by the expression described by Ramos (1999) as a function of the specific gravity as follows:

$D M=24.182+211.04 *[S G-1.0988][12]$

The calculated values of the potential yield obtained by the proposed method were correlated with the observed data from the production fields. Because the coefficients of 
correlation and determination are not always suitable to evaluate the performance of a model, the agreement index $d$ was also used (Willmott et al., 1985). The index $c$ proposed by Camargo and Sentelhas (1995) was also adopted in this article to indicate the performance of the model, putting together the accuracy $R$ and the exactness $d$ indices, being defined as the product of both indices.

The values of the tuber-specific gravity and dry matter content were obtained by the researchers from the Agronomic Institute of Campinas (IAC) at all the locations where the potato experiments were conducted from 1985 to 2005 (unpublished data).

\section{Results and Discussion}

Potato potential yield for the cultivar Itararé was calculated throughout 15 site years at four different regions of the state of São Paulo, Brazil (Tables 1 and 2) using of the mean values of global solar radiation flux density, photoperiod duration, $P A R$, air temperature, and the maximum rates of carbon dioxide assimilation obtained from Eq. [3], which are the required input variables of the proposed model.

Tuber potential yields calculated by the agrometeorological model in the study and potential yields harvested from the production fields were highly correlated, because the statistical analysis shows that over $92 \%$ of the potential yield variations can be explained by the calculated values. The corresponding values of fresh tuber yields estimated by the model varied from 16.8 to $35.7 \mathrm{t} \cdot \mathrm{ha}^{-1}$, whereas those of fresh tuber yields obtained from the production areas with an adequate soil water supply were within the range varying from 17.5 to $39.0 \mathrm{t} \cdot \mathrm{ha}^{-1}$ (Table 2). The larger difference between measured and estimated tuber yield was observed for the growing period September through January of the years 1998 and 2003 when the model slightly underestimated and overestimated potential yield at 3.3 and $3.5 \mathrm{t} \cdot \mathrm{ha}^{-1}$, respectively.

In the most important potato production areas of Argentina, Caldiz and Struit (1999) reported that actual fresh tuber yields vary from 13 to $30 \mathrm{t} \cdot \mathrm{ha}^{-1}$, whereas potential yields estimated by the LINTUL-POTATO (Research Institute for Agrobiology and Soil Fertilizer, Wageningen, The Netherlands) simulation model ranged from 47 to 126 $\mathrm{t} \cdot \mathrm{ha}^{-1}$. Differences between actual and potential yield might be attributed to suboptimal solar radiation interception by the foliage, cultivar, seed management, physiological age of the seed, suboptimal management of water and fertilizer, and inadequate control measures for early blight and late blight.

The potential yield of agronomic crops is dramatically affected by the amount of water applied during the crop-growing season at a given region. Water and temperature are important climatic factors to consider in crop modeling studies. Cooler temperatures result in delayed maturity, which provides more time for the interception of solar radiation and conversion of intercepted radiation into
Table 1. Meteorological data throughout different years and growth periods of the potato crop, cultivar Itararé (IAC-5986), grown at Itararé, Tatuí, Piracicaba, and São Manuel, state of São Paulo, Brazil.

\begin{tabular}{lclcccccr}
\hline Site & $\mathrm{Yr}$ & $\begin{array}{l}\text { Growth } \\
\text { period }\end{array}$ & $\begin{array}{c}\text { Cycle } \\
(\text { days })\end{array}$ & $\mathrm{T}\left({ }^{\circ} \mathrm{C}\right)$ & $\mathrm{n} / \mathrm{N}$ & $\begin{array}{c}\mathrm{Qg} \\
\left(\mathrm{J} \cdot \mathrm{m}^{-2} \cdot \mathrm{s}^{-1}\right)\end{array}$ & $\begin{array}{c}P A R \\
\left(\mathrm{~J} \cdot \mathrm{m}^{-2} \cdot \mathrm{s}^{-1}\right)\end{array}$ & $\mathrm{P}(\mathrm{mm})$ \\
\hline Itararé & 1985 & Mar./June & 100 & 16.5 & 0.57 & 395.0 & 176.3 & 587 \\
& 1993 & Sept./Jan. & 137 & 18.0 & 0.45 & 429.8 & 194.4 & 809 \\
& 1994 & Mar./July & 114 & 16.0 & 0.54 & 382.5 & 170.0 & 572 \\
& 1997 & Feb./July & 140 & 16.5 & 0.57 & 411.0 & 181.1 & 596 \\
& 1998 & Apr./Aug. & 112 & 15.0 & 0.57 & 378.3 & 167.9 & 505 \\
& 1998 & Sept./Jan. & 117 & 18.0 & 0.33 & 372.0 & 173.5 & 1,163 \\
& 1999 & Mar./July & 126 & 15.6 & 0.55 & 388.0 & 172.8 & 578 \\
& 2000 & Nov./Mar. & 133 & 20.2 & 0.49 & 452.1 & 204.1 & 818 \\
& 2001 & Mar./July & 102 & 16.9 & 0.55 & 392.2 & 173.5 & 549 \\
& 2003 & Sept./Jan. & 98 & 17.5 & 0.43 & 415.9 & 188.8 & 865 \\
& 2005 & Mar./July & 133 & 16.7 & 0.58 & 400.6 & 177.0 & 508 \\
& 2005 & Oct./Feb. & 122 & 18.7 & 0.41 & 413.8 & 190.2 & 935 \\
Tatuí & 2001 & Sept./Jan. & 115 & 22.8 & 0.55 & 480.0 & 212.5 & 723 \\
Piracicaba & 1989 & Oct./Feb. & 105 & 23.6 & 0.58 & 503.0 & 222.2 & 759 \\
S. Manue & 2000 & Aug./Jan. & 131 & 14.8 & 0.56 & 380.4 & 168.6 & 813 \\
\hline
\end{tabular}

$\mathrm{T}=$ daily air temperature; $\mathrm{n} / \mathrm{N}=$ insolation ratio; $\mathrm{Qg}=$ global solar radiation density flux; $P A R=$ photosynthetically active radiation; $\mathrm{P}=$ total of rainfall throughout the crop growing season. Monthly average values.

Table 2. Cultivar characteristics throughout different years and growth periods of the potato crop, cultivar Itararé (IAC-5986), grown at Itararé, Tatuí, Piracicaba, and São Manuel, state of São Paulo, Brazil, and the respective potential yield data.

\begin{tabular}{lclllllllll}
\hline Site & Yr & $\begin{array}{c}\text { Growth } \\
\text { period }\end{array}$ & CDA & LAI & C(LAI) & C(T) & HI & DM & EPY & MPY \\
\hline Itararé & 1985 & Mar./June & 41.0 & 4.34 & 0.480 & 0.6 & 0.6 & 25.0 & 17.5 & 17.5 \\
& 1993 & Sept./Jan. & 41.5 & 4.34 & 0.480 & 0.6 & 0.6 & 25.0 & 27.9 & 26.4 \\
& 1994 & Mar./July & 41.0 & 4.34 & 0.480 & 0.6 & 0.6 & 17.8 & 27.8 & 28.2 \\
& 1997 & Feb./July & 41.0 & 4.34 & 0.480 & 0.6 & 0.6 & 18.9 & 32.9 & 30.8 \\
& 1998 & Apr./Aug. & 41.0 & 4.34 & 0.480 & 0.6 & 0.6 & 22.3 & 21.4 & 20.3 \\
& 1998 & Sept./Jan. & 41.0 & 4.34 & 0.480 & 0.6 & 0.6 & 16.5 & 35.7 & 39.0 \\
& 1999 & Mar./July & 41.0 & 4.34 & 0.480 & 0.6 & 0.6 & 17.8 & 30.7 & 31.6 \\
& 2000 & Nov./Mar. & 42.0 & 4.34 & 0.480 & 0.5 & 0.6 & 18.0 & 32.0 & 31.5 \\
& 2001 & Mar./July & 41.0 & 4.34 & 0.480 & 0.6 & 0.6 & 22.3 & 19.8 & 19.5 \\
& 2003 & Sept./Jan. & 41.5 & 4.34 & 0.480 & 0.6 & 0.6 & 16.8 & 29.7 & 26.2 \\
& 2005 & Mar./July & 41.0 & 4.34 & 0.480 & 0.6 & 0.6 & 22.3 & 25.9 & 25.2 \\
Tatuí & 2005 & Oct./Feb. & 41.5 & 4.34 & 0.480 & 0.6 & 0.6 & 19.7 & 32.0 & 32.7 \\
Piracicaba & 2001 & Sept./Jan. & 46.7 & 4.34 & 0.480 & 0.5 & 0.6 & 17.8 & 30.9 & 29.2 \\
S. Manuel & 1989 & Oct./Feb. & 47.7 & 2.50 & 0.423 & 0.5 & 0.6 & 16.0 & 16.8 & 18.0 \\
\hline
\end{tabular}

$\overline{\mathrm{CDA}}=$ carbon dioxide assimilation maximum rates $\left(\mu \mathrm{L} \cdot \mathrm{cm}^{-2} \cdot \mathrm{h}^{-1}\right)$; LAI $=$ leaf area index (maximum value); $\mathrm{C}(\mathrm{LAI})=$ correction factor for leaf area index variation; $\mathrm{C}(\mathrm{T})=$ correction factor for maintenance respiration; $\mathrm{HI}=$ harvest index; $\mathrm{DM}=$ dry matter content $(\%) ; \mathrm{EPY}=$ estimated crop potential yield $\left(\mathrm{t} \cdot \mathrm{ha}^{-1}\right) ; \mathrm{MPY}=$ measured crop potential yield $\left(\mathrm{t} \cdot \mathrm{ha}^{-1}\right)$.

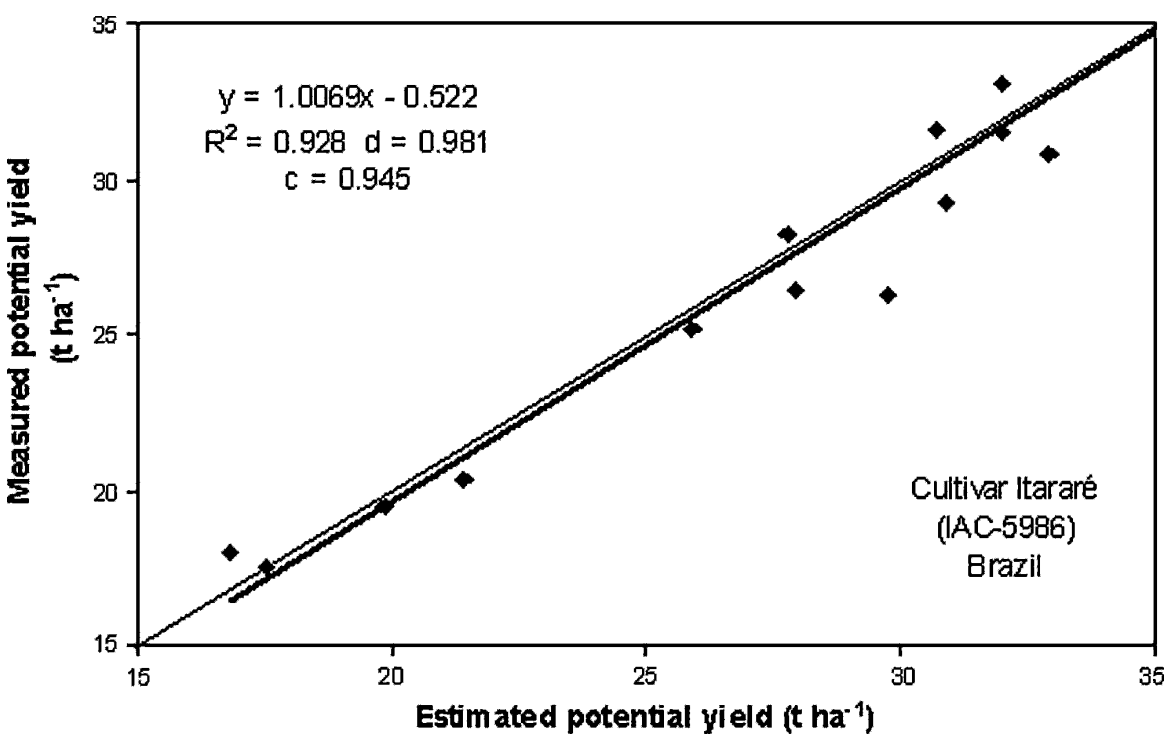

Fig. 1. Relation between observed and predicted potential potato tuber yield, cultivar Itararé (IAC-5986) for the state of São Paulo, Brazil. 
dry matter. Stark and Love (2003) point out that two major factors influence tuber yield: 1) photosynthetic activity and duration of the leaf canopy and 2) the length of the linear tuber growth phase. The longer a canopy is able to produce photosynthate at a relatively high rate, and the longer tubers are bulking at their maximum rate, the higher the yield will be in such a way as to express the productive potentiality of potato crop at a given site.

As to the effect of water application on the productive potentiality expression of potato in a determined climatic locality, Bowen (2003) reported that a reduction of only 62 $\mathrm{mm}$ in water applied resulted in a decrease in fresh tuber yield from 38.2 to $30.3 \mathrm{t} \cdot \mathrm{ha}^{-1}$. For the summer potato crop, applied water ranged from 380 to $584 \mathrm{~mm}$ and the associated yields ranged from 12.1 to $25.4 \mathrm{t} \cdot \mathrm{ha}^{-1}$. Therefore, approximately half as much water was used during the winter to produce $150 \%$ more yield than was obtained throughout the summer crop-growing season.

The differences observed on the dry matter content throughout different years and growth periods of the potato crop (Table 2) might be ascribed to climatic variations on tuber-specific gravity. Apart from the primary environmental factors affecting specific gravity of irrigated potatoes (air and soil temperatures), other weather conditions can also affect tuber-specific gravity.

Stark and Love (2003) state that high evaporative demand caused by low relative humidity, high global solar radiation flux density, or high wind speed can reduce photosynthesis by causing stomata to close with an accompanying restriction of $\mathrm{CO}_{2}$ uptake. Prolonged periods with overcast skies can also reduce light intensity to levels below that required for maximum dry matter production.

The coefficient of determination $R^{2}$ and correlation $R$ bring information about the degree of accuracy but do not reveal the exactness of the model. The index of agreement $d$ equal to 0.981 reveals a high level of exactness. The index $c$ was 0.945 for the studied sites, showing an excellent model performance according to the interpretation reported by Camargo and Sentelhas (1995). Both the model accuracy, given by the trend line, and the model exactness shown by the dispersion of the data around the fitted 1:1 line were outstanding (Fig. 1). The value of $c$ was higher than 0.93 , exceeding, therefore, the values of $d$ considered as satisfactory. The lower limit for the index $c$ recommended by Robinson and Hubbard (1990) is 0.75 .

The results showed that the agrometeorological model tested under the climatic conditions of the state of São Paulo, Brazil, in general underestimated irrigated potato yield by less than $10 \%$. This justifies the recommendation to test the performance of the model in other climatic regions for different crops and genotypes under optimal irrigation conditions in further scientific investigations.

Given the excellent performance of the model, we suggest that it can be used to forecast harvest time or be used as an effective tool to predict the suitability of potential regions to the cultivation of potato crops, cultivar Itarare (IAC-5986), in the state of São Paulo, Brazil.

\section{Conclusions}

The agrometeorological model taking into account information on LAI, photoperiod duration, $P A R$, and air temperature is feasible to estimate potential tuber yield at a commercial scale.

\section{Literature Cited}

Assunção, H.F. 1994. Relações entre radiação fotossinteticamente ativa e radiação solar global em Piracicaba, SP. Piracicaba. Escola Superior de Agricultura 'Luiz de Queiroz', Universidade de São Paulo. MSc Diss.

Bowen, W.T. 2003. Water productivity and potato cultivation, p. 229-238. In: Kijne, J.W., R. Barker, and D. Molden (eds.). Water productivity in agriculture: Limits and opportunities for improvement. $\mathrm{CAB}$ International. Sri Lanka. 27 Nov. 2005. <http://www.iwmi. cgiar.org/pubs/Book/CA_CABI_Series/Water_ Productivity/Protected/0851996698ch14.pdf>.

Caldiz, D.O. and P.C. Struit. 1999. Survey of potato production and possible yield constraints in Argentina. Potato Research 42: 51-71.

Camargo, A.P. and P.C. Sentelhas. 1995. Avaliação de modelos para estimativa da evapotranspiração potencial mensal em base diária para Campinas e Ribeirão Preto, SP. In: Congresso Brasileiro de Agrometeorologia, Vol. 7, Anais. Campina Grande. p. 415-417.

Cervellini, A., E. Salati, and H. Godoy. 1966. Estimativa da distribuição da energia solar no Estado de São Paulo. Bragantia 25:31-40.

Coelho, D.T. and R.F. Dale. 1980. An energy-crop growth variable and temperature function for predicting corn growth and development. Planting to silking. Agron. J. 72:503-510.

Crommelynk, D. and A. Fichot. 1997. Solar constant temporal and frequency characteristics. Royal Meteorological Institute of Belgium, Bruxelas. 13 Feb. 2003. <http://estirm2.oma.be/ solarconstant/sarr/sarr.html>.

Doorenbos, J. and A.H. Kassam. 1979. Yield response to water. Irrigation and Drainage Paper, 33. FAO, Rome, Italy.

Haverkort, A.J. 1990. Ecology of potato cropping systems in relation to latitude and altitude. Agr. Syst. 32:251-272.

Kadaja, J. and H. Tooming. 2004. Potato production model based on principle of maximum plant productivity. Agr. For. Meteorol. 127: $1-16$.

Kooman, P.L. and A.J. Haverkort. 1995. Modelling development and growth of the potato crop influenced by temperature and daylength: LINTUL-POTATO. In: Haverkort, A.J. and D.K.L. Mac Kerron (eds.) Potato ecology and modelling of crops under conditions limiting growth. Kluwer Academic Publishers, Dordrecht, p. 41-60.

Ku, S.B., G.E. Edwards, and C.B. Tanner. 1977. Effects of light, carbon dioxide, and temperature on photosynthesis, oxygen inhibition of photosynthesis, and transpiration in Solanum tuberosum. Plant Physiol. 59:868-872.

Manrique, L.A. and D.P. Bartholomew. 1991. Growth and yield performance of potato grown at three elevations in Hawaii: II. Dry matter production and efficiency of partitioning. Crop Sci. 31:367-372.

Midmore, D.J. and R.K. Prange. 1992. Growth responses of two Solanum species to contrasting temperatures and irradiance levels: Relations to photosynthesis, dark respiration and chlorophyll fluorescence. Annuals of Botany 69:13-20.

Penning de Vries, F.W.T., D.M. Jansen, H.F.M. Jen Berge, and A. Bakema. 1989. Simulation of ecophysiological process of growth in several annual crops. Pudoc, Wageningen.

Pereira, A.B. and C.C. Shock. 2006. Development of irrigation best management practices for potato from a research perspective in the United States. 1:1-20. <http://www.sakia.org/>.

Pereira, A.B., N.A. Villa Nova, and E. Galvani. 2003. Estimation of global solar radiation flux density in Brazil from a single measurement at solar noon. Biosystems Engineering 86:27-34. $<\mathrm{http}: / /$ www.sciencedirect.com $>$.

Ramos, V.J. 1999. Produção e qualidade da batata (Solanum tuberosum spp. tuberosum), cv. Itararé (IAC-5986) em função do peso do tubérculo semente, densidade de plantas e adubação. Botucatu. Faculdade de Ciências Agronômicas, Universidade Estadual Paulista. PhD Thesis.

Robinson, J.M. and K.G. Hubbard. 1990. Soil water assessment model for several crops in high plains. Agron. J. 82:1141-1148.

Robles, W.G.R. 2003. Dióxido de carbono via fertirrigação em batateira (Solanum tuberosum L.) sob condições de campo. Piracicaba. Escola Superior de Agricultura 'Luiz de Queiroz', Universidade de São Paulo. PhD Thesis.

Sarquis, J.I., H. Gonzalez, and I. Bernal-Lugo. 1996. Response of two potato clones (Solanum tuberosum L.) to contrasting temperature regimes in the field. American Potato Research 73:285-300.

Stark, J.C. and S.L. Love. 2003. Tuber quality, p. 329-343. In: Stark, J.C. and S.L. Love (eds.). Potato production systems. University of Idaho Extension, Moscow, ID.

Stuttle, G.W., N.C. Yorio, and R.M. Wheeler. 1996. Interacting effects of photoperiod and photosynthetic photon flux on net carbon assimilation and starch accumulation in potato leaves. J. Amer. Soc. Hort. Sci. 121:264-268.

van Heemst, H.D.J. 1986. Physiological principles, p. 13-26. In: van Keulen, H. and J. Wolf (eds.). Modelling of agricultural production: Weather, soils and crops. Pudoc, Wageningen.

Varillas, I.T. 1991. Determinação de unidades térmicas e avaliação dos efeitos de níveis térmicos elevados sobre o crescimento e a produção de cultura de batata (Solanum tuberosum L.). Piracicaba. Escola Superior de Agricultura 'Luiz de Queiroz', Universidade de São Paulo. MSc Diss.

Villa Nova, N.A., F.G. Pilau, D. Dourado Neto, and P.A. Manfron. 2005. Estimativa da produtividade de cana-de-açúcar irrigada com base na fixação de $\mathrm{CO}_{2}$, radiação solar e temperatura do ar. Revista Brasileira de Agrometeorologia 13:405-411

Villa Nova, N.A., A.V. Santiago, and F.C. Rezende. 2001. Energia Solar. Aspectos físicos de captura pela biomassa. Departamento de Ciências Exatas: Escola Superior de Agricultura Luiz de Queiroz, Universidade de São Paulo.

Willmott, C.J., S.G. Ackleson, R.E. Davies, J.J Feddema, K.M. Klink, D.R. Legates, J. O'Donnell, and C.M. Rowe. 1985. Statistics for the evaluation and comparison of models. J. Geophys. Res. 90:8995-9005. 